\title{
Correction to: Towards an Autonomous Pelagic Observatory: Experiences from Monitoring Fish Communities around Drifting FADs
}

\author{
Patrice Brehmer $^{1} \cdot$ Gorka Sancho $^{2} \cdot$ Vasilis Trygonis $^{3} \cdot$ David Itano $^{4} \cdot$ John Dalen $^{5} \cdot$ Ariel Fuchs $^{6} \cdot$ Abdelmalek Faraj $^{7}$. \\ Marc Taquet ${ }^{8}$
}

Published online: 2 October 2018

(C) The Author(s) 2018

\section{Correction to: Thalassas: An International Journal of Marine Sciences https://doi.org/10.1007/s41208-018-0107-9}

The article "Towards an Autonomous Pelagic Observatory: Experiences from Monitoring Fish Communities around Drifting FADs", written by Patrice Brehmer, Gorka Sancho, Vasilis Trygonis, David Itano, John Dalen, Ariel Fuchs, Abdelmalek Faraj, and Marc Taquet, was originally published electronically on the publisher's internet portal (currently SpringerLink) 24 August 2018 without open access. With the author(s)' decision to opt for Open Choice the copyright of the article changed on 05 October 2018 to (C) The Author(s) 2018 and the article is forthwith distributed under the terms of the Creative Commons Attribution 4.0 International License (http://creativecommons.org/licenses/ by/4.0/), which permits use, duplication, adaptation, distribution and reproduction in any medium or format, as long as you give appropriate credit to the original author(s) and the source, provide a link to the Creative Commons license and indicate if changes were made.

The original article has been corrected.

Open Access This article is distributed under the terms of the Creative Commons Attribution 4.0 International License (http://creativecommons. org/licenses/by/4.0/), which permits unrestricted use, distribution, and reproduction in any medium, provided you give appropriate credit to the original author(s) and the source, provide a link to the Creative Commons license, and indicate if changes were made.
The online version of the original article can be found at https://doi.org/ $10.1007 / \mathrm{s} 41208-018-0107-9$

Patrice Brehmer

Patrice.Brehmer@ird.fr

1 Institut de Recherche pour le Développement (IRD), Campus Ifremer, Délégation régional IRD France-Ouest, UMR LEMAR, BP 7029280 Plouzané, France

2 College of Charleston, 205 Fort Johnson Rd, Charleston, SC 29412 , USA

3 Department of Marine Sciences, University of the Aegean, University Hill, 81100 Mytilene, Greece
4 University of Hawaii at Manoa, 1000 Pope Road, MSB 312, Honolulu, HI 96 822, USA

5 Institute of Marine Research, P.O. Box 1870, 5817 Nordnes, Bergen, Norway

6 Out-There Science Consulting, Sustainable Strategies \& Opportunities, 10 rue du Levant, 34280 La Grande Motte, France

7 Institut National de Recherche Halieutique (INRH), Route de Sidi Abderrahmane, Casablanca, Morocco

8 Institut de Recherche pour le Développement (IRD), UMR EIO (UPF-Ifremer-IRD-ILM) BP 52998713, Papeete, French Polynesia 